\title{
Government conservation policies on Mexican coastal areas: is "top-down" management working?
}

\author{
Héctor Nava \& M. Teresa Ramírez-Herrera \\ Centro de Investigaciones en Geografía Ambiental, Universidad Nacional Autónoma de México, campus Morelia. Antigua \\ carretera a Pátzcuaro 8701, Colonia Ex-hacienda de San José de la Huerta, C.P. 58190, Morelia Michoacán, México; \\ oemith@gmail.com,mtramirez@ciga.unam.mx
}

Received 26-I-2011. C Corrected 10-IV-2011. Accepted 12-V-2011.

\begin{abstract}
Marine and terrestrial ecosystems are declining globally due to environmental degradation and poorly planned resource use. Traditionally, local government agencies have been responsible of the management of natural reserves to preserve biodiversity. Nonetheless, much of these approaches have failed, suggesting the development of more integrative strategies. In order to discuss the importance of a holistic approach in conservation initiatives, coastal and underwater landscape value and biological/environmental indicators of coral reef degradation were assessed using the study case of Zihuatanejo, Guerrero coastal area. This area shelters representative coral reef structures of the Eastern Pacific coast and its terrestrial biodiversity and archaeology enhance the high value of its coastal area. This study explored the landscape value of both terrestrial and marine ecosystems using the geomorphosite approach in two sites on the Zihuatanejo coastal area: Caleta de Chon and Manzanillo Beach. Sedimentation rate, water transparency, chlorophyll and total suspended solids were recorded underwater in each site for environmental characterization. 50 photo-quadrants on five transects were surveyed between 3-4m depth to record coverage (\%) of living corals, dead corals, algae, sand and rocks. The conservation status of coral reefs was assessed by the coral mortality index (MI). Landscape values showed that both terrestrial and marine ecosystems had important scientific and aesthetic values, being Manzanillo Beach the site with the highest potential for conservation initiatives $(\mathrm{TtV}=14.2)$. However, coral reefs face elevated sedimentation rates (up to $1.16 \mathrm{~kg} / \mathrm{m}^{2} \mathrm{~d}$ ) and low water transparency (less of $5 \mathrm{~m}$ ) generated by coastal land use changes that have increased soil erosion in the adjacent coastal area. High coverage of dead corals (23.6\%) and algae (up to $29 \%$ ) confirm the low values in conservation status of coral reefs ( $\mathrm{MI}=0.5)$, reflecting a poorly-planned management. Current conditions are the result of "top-down" conservation strategies in Zihuatanejo, as Federal and Municipal authorities do not coordinate, disregard local community in coral reef management, and ignore the intimate relationship between the coastal and marine realms. This work confirms the importance of conservation strategies with a holistic approach, considering both terrestrial and marine ecosystems in coastal areas; and that these initiatives should include local coastal communities in management and decision-taking processes done by government authorities. Rev. Biol. Trop. 59 (4): 1487-1501. Epub 2011 December 01.
\end{abstract}

Key words: conservation, coral reefs, Mexican Pacific coast, coastal management, government policies, Natural Protected Areas.

Worldwide, some of the major barriers to accomplish conservation goals in coastal areas are the difficulty to understand the human impact in natural systems (Granja-Fernández \& López-Pérez 2009, Risk et al. 2009, Selkoe et al. 2009) and the integration of a holistic approach that considers both terrestrial and aquatic ecosystems (Crosby et al. 2002,
Herbert et al. 2010). Natural Protected Areas (NPAs) are the chief legal instruments for biodiversity conservation, and they have grown in importance globally (Moreno-Casasola et al. 2005, Ban 2009, Herbert et al. 2010). Around the globe, protected areas cover up to $12 \%$ of non-marine Earth surface (Herbert et al. 2010) and $5.9 \%$ of its territorial seas (WDPA 2004). 
The establishment of NPAs in several coastal and marine areas has been promoted by the presence of coral reefs due to their high ecological, aesthetic, cultural and scientific value (White et al. 1994, 2000, Moberg \& Folke 1999, Crosby et al. 2002, McClanahan 2002). However, coral coverage continues declining around the world as a consequence of climate change and environmental degradation and the establishment of NPAs seems to be not enough to protect these ecosystems. A holistic approach that includes an adequate management of terrestrial and marine ecosystems and local community involvement is crucial to preserve this natural heritage (Cinner \& Pollnac 2004, McClanahan et al. 2006, Camargo et al. 2009, Ramírez-Herrera et al. 2010). Around the world, many valuable studies report the effect of direct activities on coral reefs such as fishing and recreational diving (Coblentz 1997, Hawkins et al. 1999, Jameson et al. 1999, Tratalos \& Austin 2001, Zakai \& Chadwick-Furman 2002, Hawkins \& Roberts 2004, Bartholomew et al. 2008). However, coral reefs in many developing countries are close to coastal villages and cities, and remain exposed to human impact resulting from urban development and the use of inland natural resources with no adequate management strategies. Summarizing management strategies in NPAs around the world, they outline that "top-down" (state or agency control) conservation policies give poorer results with regard to "bottom-up" (community-based) resource management, since people who depend upon the marine resources are the best managers. In coastal areas near coral reefs, non-planned management can cause deterioration in the marine ecosystem due to human actions such as land transformation and deforestation that promote coastal erosion. These actions can create harmful conditions for coral survival such as high sedimentation, low water transparency, high concentration of suspended matter and nutrients in ocean water (Cortés \& Risk 1985, Edinger et al. 1998, Hodgson 1999, Risk et al. 2009). For this reason, potential sources of negative impact coming from the coast also require attention for coral reef conservation.
In México, the establishment of 55 NPAs that cover only $4 \%$ of coastal and marine areas (CONANP 2009) shows the level of government initiatives for marine ecosystem protection. The occurrence of coral reefs has triggered the recognition of some of these NPAs (INE 1998, CONANP 2006, Rioja-Nieto \& Sheppard 2008, López-Pérez \& LópezGarcía 2009). However, community involvement is not considered for the management of many of these NPAs and some of them can be subjected to land use change in order to meet urban needs. This study was performed on the coastal area of Zihuatanejo, Guerrero, in the southern Mexican Pacific coast. Here, topdown conservation strategies have ignored the effect of land use changes in the marine realm. Several studies testify the existence of representative coral reef structures of the Eastern Pacific coast (Reyes-Bonilla 2003, Carriquiry \& Reyes-Bonilla 1997, Victoria-Salazar 2007) and terrestrial biodiversity and archaeology enhance the high value of this coastal area (this study). Our goal is to validate the importance of integrative strategies for coastal-marine conservation, using the study case of Zihuatanejo coral reef coast, which has used a "top-down" management strategy. To test the results of this strategy, we assessed the anthropogenic impact in the area, by performing a series of biological/environmental analysis indicative of coral reef degradation. Results on the conservation status of the Zihuatanejo coastal and underwater landscape value, and the environmental indicators of coral reef degradation, are used to support a change from a "top down" to "bottom-up" (community-based) resource management for the Zihuatanejo coastal-marine conservation.

\section{MATERIALS AND METHODS}

Study area: Zihuatanejo is an important tourist destination of over 62000 inhabitants and with more than 700000 tourists per year (INEGI 2008). It is located inside the Tlacoyunque Priority Marine Area (PMA) (Fig. 1). Mexican PMAs have been proposed 
to promote scientific knowledge and conservation of biodiversity in national marine areas (Vázquez-Domínguez et al. 1998), but they do not provide legal protection for the natural resources (Fig. 2). However, biodiversity inside Tlacoyunque PMA has been considered under protection (CONABIO 2009), since it overlaps with a Natural Protected Area with Federal jurisdiction (Figs. 1, 2). This NPA is named Playa Piedra del Tlacoyunque, a Sanctuary with less than $11.9 \mathrm{~km}$ long that protects a breeding site of sea turtles (SEMARNAT 2002, Fig. 2). Another category of Natural Protected Areas in Zihuatanejo is the Ecological Reserves that have Municipal jurisdiction. Until 2004, the Ecological Reserve of Cerro del Vigía (Figs. 1,2) protected the tropical deciduous forest and their associated fauna, extending over the hills surrounding
Zihuatanejo bay, up to an elevation $70 \mathrm{~m}$ above sea level. After 2004, Municipal authorities of Zihuatanejo changed the status of the Ecological Reserve of Cerro del Vigía, to the status of residential tourist area. Using this change in land use, the Secretariat of Environmental and Natural Resources (SEMARNAT 2010) authorized the deforestation of about 17 ha of native vegetation between 2005 and 2007. Before the current study, the outcomes of this land transformation on the marine ecosystem were unknown. Therefore, study sites for this work are selected because of their representative reef structures and their location close to the deforestation area on Cerro del Vigía hills (Fig. 1).

Caleta de Chon $\left(17^{\circ} 36,56.68^{\prime \prime} \mathrm{N}\right.$ 101 33 '16.57" W) and Manzanillo Beach $\left(17^{\circ} 37^{\prime} 11.40^{\prime \prime} \mathrm{N}-101^{\circ} 31^{\prime} 27.60 \mathrm{~W}\right)$ harbor fringing reefs, formed mainly by corals of the

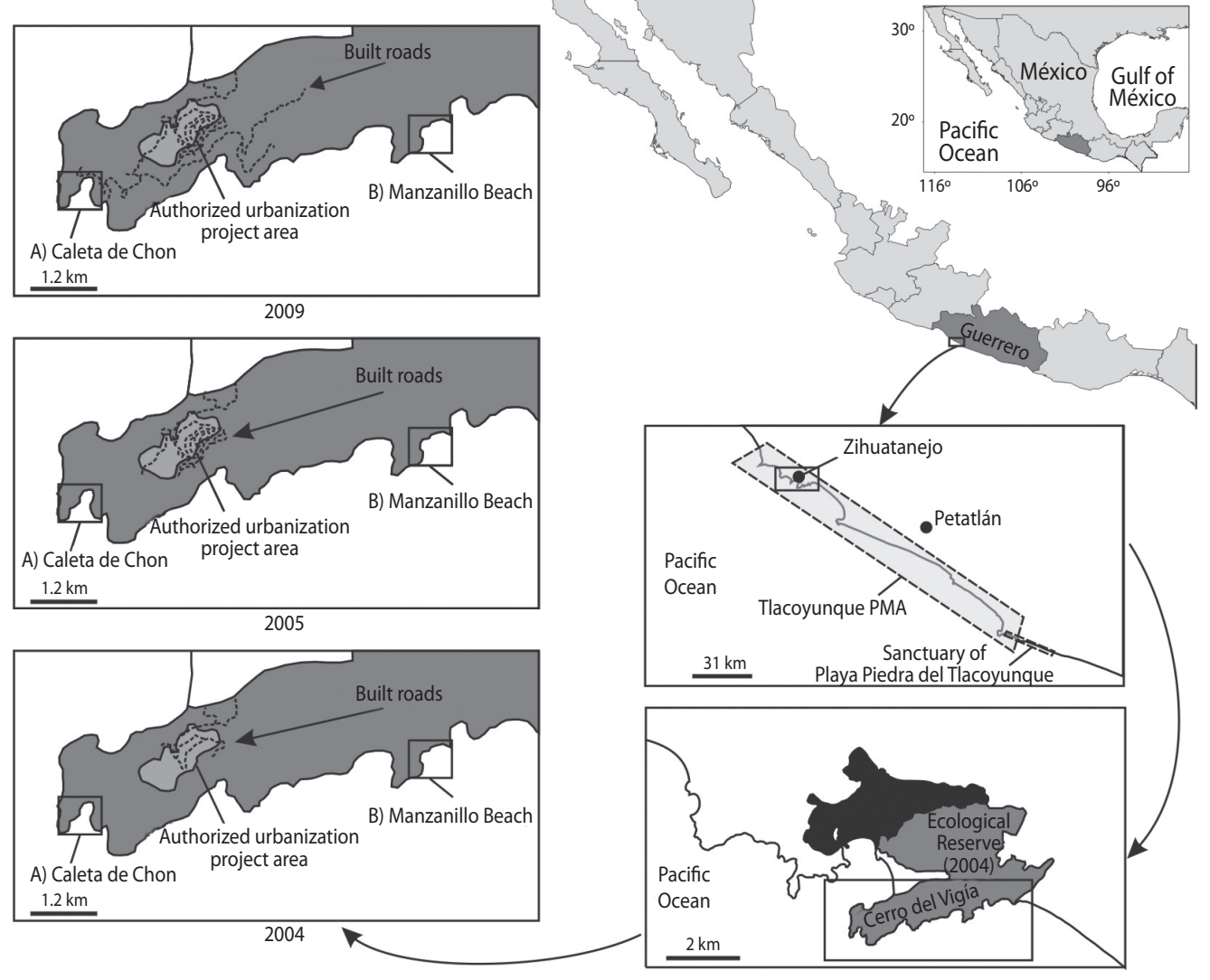

Fig. 1. Study area and location maps where coral reefs are distributed. (A) Caleta de Chon; and (B) Manzanillo Beach. 

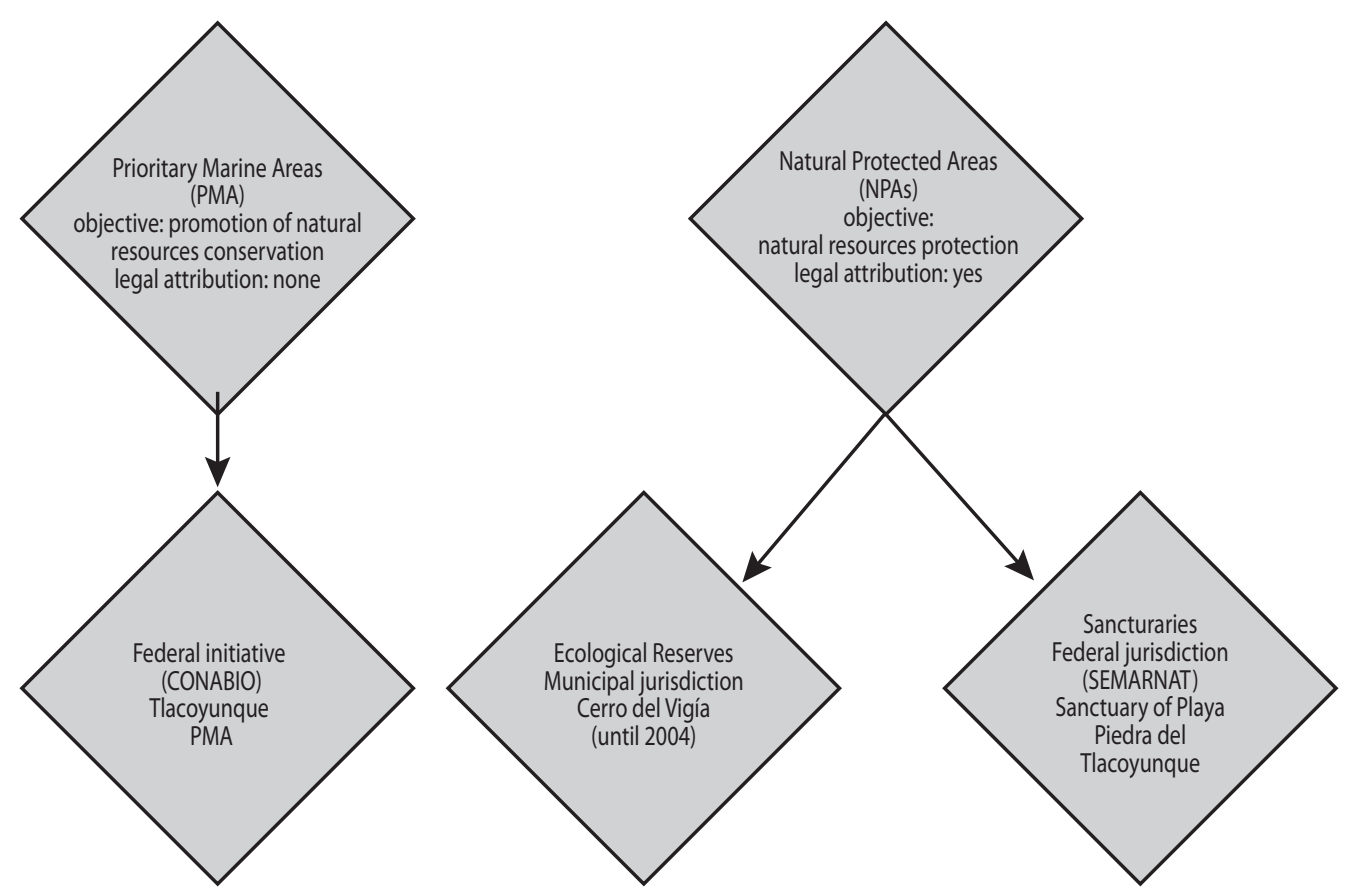

Fig. 2. Diagram showing conservation and protection initiatives in the coastal and marine realm of Zihuatanejo Guerrero.

genus Pocillopora. Caleta de Chon is located within a small cove, with a maximum depth $c a$. $13 \mathrm{~m}$. A rocky sea floor covers the periphery, and a sandy bottom occupies the center of the cove. Coral reef in Manzanillo Beach is located in an open beach, with a depth up to $4 \mathrm{~m}$. Its sandy floor is partially covered with numerous patches of rocky substratum that allows the growth of corals. At some places, this reef structure reaches $1.5 \mathrm{~m}$. Recreational scuba diving and artisanal fishing activities are practiced at both reefs and contribute to the local economy.

Environmental characterization: Storms and sediment runoff may occur during the rainy season, and the anthropogenic effect can be disguised under these conditions. Hence, to detect signs of environmental degradation on the marine ecosystem of human origin, a set of environmental parameters was measured during the dry season (May 2009) hence the environmental conditions represent the less stressful during the year. The transparency of water column (m) was estimated three times at each reef, using standard Secchi disk extinction depth measurements (Edinger et al. 1998). To estimate the sedimentation rate $\left(\mathrm{kg} / \mathrm{m}^{2} \mathrm{~d}\right)$, six sediment-collecting bottles of one liter were attached to three vertical PVC pipes (1 $\mathrm{m}$ long each) anchored above each reef floor to $3-4 \mathrm{~m}$ depth. Sediments collected during four days were rinsed at the laboratory with fresh water and later were oven-dried and weighted (Cortés \& Risk 1985). To record the concentration of total suspended solids (TSS, mg/L) and chlorophyll a $\left(\mathrm{mg} / \mathrm{m}^{3}\right)$, three seawater samples of three liters were taken three times in each site and were individually filtered into previously dried and weighed $47 \mathrm{~mm}$ glass fiber filters. Filters with sample were kept in darkness and under $4^{\circ} \mathrm{C}$ until they were processed in the laboratory. For TSS measurement, the dry weight of each filter was subtracted from its 
gross dry weight including the sample. Measurement of chlorophyll concentration was made following the method by Rogers et al. (1994). Filters with sample were placed into $15 \mathrm{~mL}$ centrifuge tubes with $10 \mathrm{~mL}$ of $90 \%$ acetone and shaken. Centrifuge tubes were kept in dark and refrigerated during $24 \mathrm{~h}$ and afterwards mixed and centrifuged for 10 minutes at 4000rpm. Using a spectrophotometer, the extinction at $750,664,647$, and $630 \mathrm{~nm}$ were measured in each sample. To correct extinction measures, the $750 \mathrm{~nm}$ reading was subtracted from the 664,647 and $630 \mathrm{~nm}$ readings. The amount of chlorophyll $a\left(\mathrm{mg} / \mathrm{m}^{3}\right)$ was calculated using the following formulas:

$$
\text { Chlorophyll } \mathrm{a}=11.85 \mathrm{E}_{664}-1.54 \mathrm{E}_{647}-0.08 \mathrm{E}_{630}
$$

where E represents absorbance at noted wavelengths (corrected by $750 \mathrm{~nm}$ reading).

$$
\left(\frac{\begin{array}{c}
\text { Chlorophyll a concentration }\left(\mathrm{mg} / \mathrm{m}^{3}\right)= \\
\text { chlorophyll a } * \mathrm{~mL} \text { acetone }
\end{array}}{\mathrm{N} .^{\circ} \text { liters of filtered sea water } * \text { cm path lenght }}\right)
$$

Coral reef conservation status: Coverage of live corals (LC), dead coral framework (DC), algae, sand and rocks were quantified using ten $20 \mathrm{~m}$-long photo-transects, recording the proportion $(\%)$ covered by each category in ten photo-quadrants of $1 \mathrm{~m}^{2}$ per transect. Each image was analyzed with CPCe (Coral Point Count with Excel extensions) software developed by the National Coral Reef Institute (FL, USA), using 100 random dots.

To assess the conservation status of each coral reef, the coral mortality index (MI) (Gómez et al. 1994) was used.

$$
\mathrm{MI}=\frac{(\mathrm{DC})}{(\mathrm{LC}+\mathrm{DC})}
$$

where DC is the coverage of the dead coral framework (even that covered with algae) and LC is the coverage of live corals. MI could range from cero (coverage of LC is $100 \%$, that indicates a coral reef in excellent conservation status), to one (coverage of DC is $100 \%$, that indicates a devastated coral reef).

Treatment of environmental and biological data: Both environmental and biological data were tested for normality and homogeneity of variances. A series of separate one-way analyses of variance (ANOVA) were conducted on the environmental parameters to test the hypothesis that environmental characteristics on the two sites did not differ significantly. Coverage data were not normally distributed (Kolmogorov-Smirnov test, Sokal \& Rohlf 1981). Accordingly, differences between sites in the coverage of live corals, dead coral framework and the different categories of algae were tested using the Mann-Whitney U test.

Coastal and underwater landscape assessment: Coastal and underwater landscape value and its quality were assessed following a standard landscape evaluation method (Reynard 2005, Pereira et al. 2007, Rovere et al. 2007) at both Manzanillo Beach and Caleta de Chon sites. This landscape evaluation method uses the "geomorphosite" concept (Panizza 2001). It is, in its narrow definition, any part of the Earth's surface that is important to the knowledge of Earth, climate and life history (Reynard 2005). It is understood to be a landform that acquired a special value due to human perception or exploitation (Panizza 2001). This value may vary, depending on the focus: scientific, ecological, cultural, aesthetic and/or economic (Reynard 2005). Landscape in this study includes both terrestrial-coastal and submerged landscapes (i.e. coral reefs as organic landforms) because they are intimately related in a feedback relationship.

Geomorphic (landscape) knowledge of the area was used and includes information on the regional setting, types of landforms and processes, structural framework, climatic aspects, human activities, geomorphic mapping, as well as another relevant natural (e.g. biodiversity, flora and fauna) and cultural aspects (e.g. archaeology) (Ramírez-Herrera et al. 2010). 
Using this information, landscape, scientific, ecological, cultural and aesthetic characteristics were identified. The assessment of the studied sites included two main stages: inventory and quantification (numerical assessment and ranking). During the inventory, geomorphosites are selected and characterized. During quantification, importance of sites is determined by attribution of values to predetermined criteria. This evaluation processes allows comparison of sites. The main objective of the inventory stage is the selection of landforms that can be defined as geomorphosites. The selection process includes using predefined set of criteria: 1) "scientific value", defined by a geomorphological characterization of the area or on former scientific research; 2) value of landform aesthetics and characteristics, in relation to sites in the same or other areas; 3 ) links between landforms and cultural elements, such as archeological features, human settlements, agriculture, buildings of historical value; 4) links between landforms and ecological issues, such as fauna and flora populations. A weight, for quantification and comparison of the two sites, was given to the initial qualitative data collected following standard method proposed by Pereira et al. (2007).

\section{RESULTS}

Environmental data: The sedimentation rate was higher at Caleta de Chon $(1.16 \mathrm{~kg} /$ $\left.\mathrm{m}^{2} \mathrm{~d}\right)$ than at Manzanillo Beach $\left(0.6 \mathrm{~kg} / \mathrm{m}^{2} \mathrm{~d}\right)$ ( $\mathrm{F}=483.66, \mathrm{p}<0.001$, respectively, Fig. 3). There were no significant differences between sites for the remaining environmental parameters (Fig. 3). The concentration of total suspended solids oscillated from 32.5 to $42.0 \mathrm{mg} / \mathrm{L}$ $(35.9 \pm 3.7 \mathrm{mg} / \mathrm{L})$ at Caleta de Chon and from 39.5 to $39.9 \mathrm{mg} / \mathrm{L}(39.7 \pm 0.2 \mathrm{mg} / \mathrm{L})$ at Manzanillo Beach. Water transparency oscillated from 4 to $6.4 \mathrm{~m}(4.9 \pm 0.9 \mathrm{~m})$ at Caleta de Chon and from 2.5 to $4 \mathrm{~m}(3.4 \pm 0.6 \mathrm{~m})$ at Manzanillo Beach. Chlorophyll a concentration was similar in both sites (1.3mg/m³ $)$ (Fig. 3).
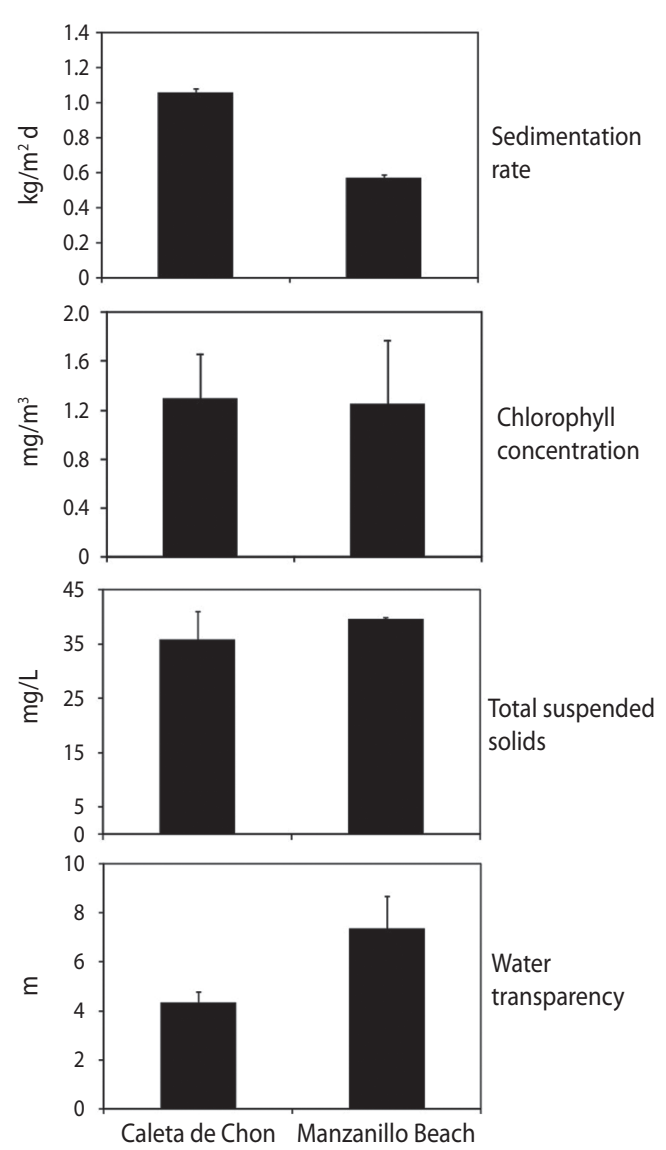

Fig. 3. Average records of environmental parameters at Caleta de Chon and Manzanillo Beach. Vertical lines indicate standard deviations.

Coral reef conservation status: Coral reefs at both study sites consist mainly of species belonging to the genus Pocillopora. At Caleta de Chon, five coral species were found and Pocillopora verrucosa was the most abundant species. The coral reef at this site extends as a fringe between 0.5 and $5 \mathrm{~m}$ deep and covers an area of $976 \mathrm{~m}^{2}$ close to the periphery of the cove. The coral reef at Manzanillo Beach harbors six species, being Pocillopora damicornis the most abundant species. The coral reef at this site is the largest structure, and it reaches an area of $5343 \mathrm{~m}^{2}$. Coral mortality index was lower in the reef at Caleta de Chon than at the Manzanillo Beach reef ( $\mathrm{MI}=0.1$ vs. 0.58, 


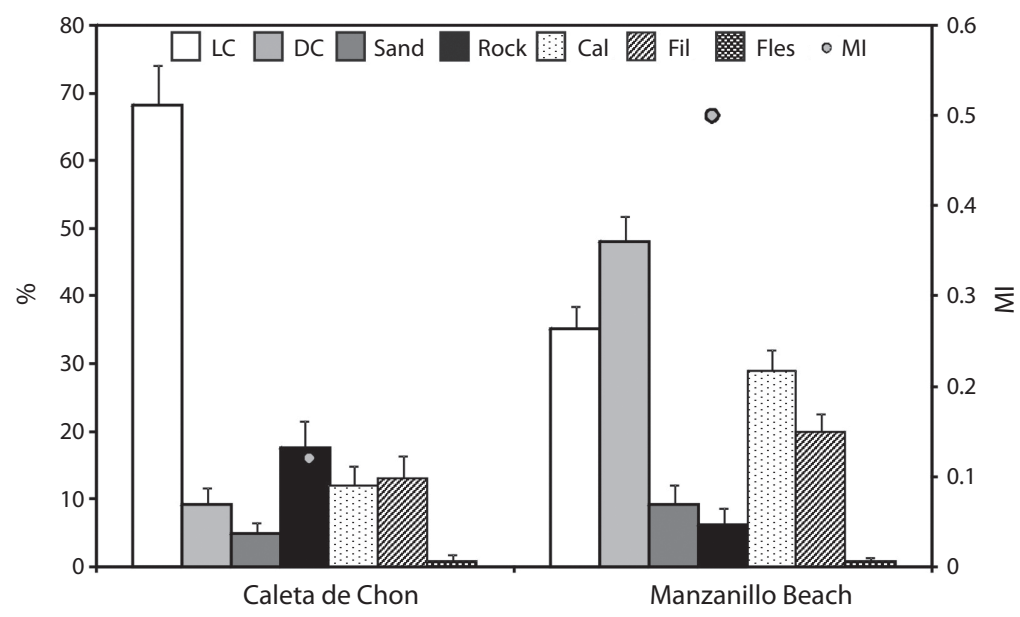

Fig. 4. (LC) Average coverage of live corals; (DC) dead coral reef matrix; sand; rocks; (Cal) calcareous algae, (Fil) filamentous algae; and (Fles) fleshy algae at Caleta de Chon and Manzanillo Beach. The coral mortality index (MI) is indicated in the second Y-axis. Vertical lines indicate standard deviation.

TABLE 1

Mean and standard deviation (mean \pm SD) for the coverage $(\%)$ of substrata components recorded in Caleta de Chon and Manzanillo Beach

\begin{tabular}{|c|c|c|c|c|c|c|c|c|c|c|c|c|c|c|c|}
\hline Site & $\begin{array}{c}\text { Transects } \\
n\end{array}$ & \multicolumn{2}{|c|}{$\begin{array}{l}\text { Live } \\
\text { corals }\end{array}$} & \multicolumn{2}{|c|}{$\begin{array}{l}\text { Dead } \\
\text { corals }\end{array}$} & \multicolumn{2}{|c|}{ Sand } & \multicolumn{2}{|c|}{ Rocks } & \multicolumn{2}{|c|}{$\begin{array}{c}\text { Calcareous } \\
\text { algae }\end{array}$} & \multicolumn{2}{|c|}{$\begin{array}{l}\text { Filamentous } \\
\text { algae }\end{array}$} & \multicolumn{2}{|c|}{$\begin{array}{l}\text { Fleshy } \\
\text { algae }\end{array}$} \\
\hline Caleta de Chon & 3 & 68.3 & 5.9 & 9.3 & 2.3 & 4.9 & 1.6 & 17.5 & 4.0 & 12.0 & 2.9 & 13.0 & 3.4 & 0.9 & 0.8 \\
\hline Manzanillo Beach & 10 & 35.2 & 3.5 & 48.1 & 3.4 & 9.3 & 1.8 & 6.3 & 1.6 & 29.1 & 2.4 & 20.0 & 1.9 & 0.9 & 0.3 \\
\hline Manzanillo Beach $(\mathrm{N})^{*}$ & 6 & 18.2 & 3.2 & 64.5 & 3.7 & 11.5 & 2.7 & 5.8 & 2.2 & 36.8 & 3.1 & 24.4 & 2.6 & 1.4 & 0.5 \\
\hline Manzanillo Beach $(\mathrm{NW})^{*}$ & 4 & 60.7 & 5.1 & 23.6 & 3.9 & 6.0 & 1.9 & 7.1 & 2.2 & 17.4 & 2.8 & 13.3 & 2.3 & 0.1 & 0.1 \\
\hline
\end{tabular}

$\mathrm{n}$ is transect number. The substrata coverage is also indicated inside the Northern zone $(\mathrm{N})$ and Northwest zone (NW) of Manzanillo Beach.

respectively) (Fig. 4). The coverage of live corals is also higher at Caleta de Chon $(68.3 \%)$ than at Manzanillo Beach (35.2\%) (Table 1) (Mann-Withney U test, $\mathrm{p}<0.05$ ). In contrast, the coverage of the dead coral framework is lower at Caleta de Chon (9.3\%) than at Manzanillo Beach $(48.1 \%)$ (Mann-Whitney U test, $\mathrm{p}<0.001)$. Caleta de Chon also has a lower coverage of calcareous $(12 \%)$ and filamentous algae $(13.0 \%)$ with regard to Manzanillo Beach (29.1 and 20.0\%, respectively) (Mann-Withney $\mathrm{U}$ test, $\mathrm{p}<0.001$ for calcareous algae and $\mathrm{p}<0.05$ for filamentous algae). The coverage of fleshy algae is similar in both localities $(0.9 \%$, Mann-Whitney $U$ test, $p>0.05$ ), and the same is the case for the coverage of rocks (17.5 to $6.3 \%$, Mann-Whitney U test, $\mathrm{p}>0.05$ ) and sand (4.9 to $9.3 \%$, Mann-Whitney U test, $\mathrm{p}>0.05$ ) (Fig. 4, Table 1).

It is important to emphasize that at Manzanillo Beach, the Northern zone of the coral reef shows important degradation signs (Table 1 ), since the coverage of live corals in the Northern zone is lower $(18.2 \%)$ than in the Northwest one (60.7\%) (Mann-Whitney U test, $\mathrm{p}<0.05)$, and the opposite case is found with 
the coverage of dead corals (64.5 vs. $23.6 \%$, respectively), calcareous algae (36.8 vs. $17.4 \%$, respectively) and filamentous algae (24.4 vs. $13.3 \%$, respectively) (Mann-Whitney U test, $\mathrm{p}<0.001$ for the coverage of dead corals and for calcareous and filamentous algae).

Landscape value: Results for the numerical landscape (geomorphosite) assessment and ranking shows that Manzanillo Beach has the most valuable landscape of the two sites, scoring higher in total value and in ranking. Manzanillo Beach terrestrial and underwater landscape shows a slightly higher scientific value (3.75) over Caleta de Chon (3.42) assigned by the site rareness in relation to the area, integrity and intactness, representativeness and pedagogical value, diversity, other geological features with heritage value, scientific knowledge and rareness at a national level. The aesthetics (an additional value) is also higher (1) at Manzanillo Beach (Fig. 5). Caleta de Chon and Manzanillo Beach had a similar protection value (3), which reflects the vulnerability and integrity of the sites and was measured by the site integrity or intactness and
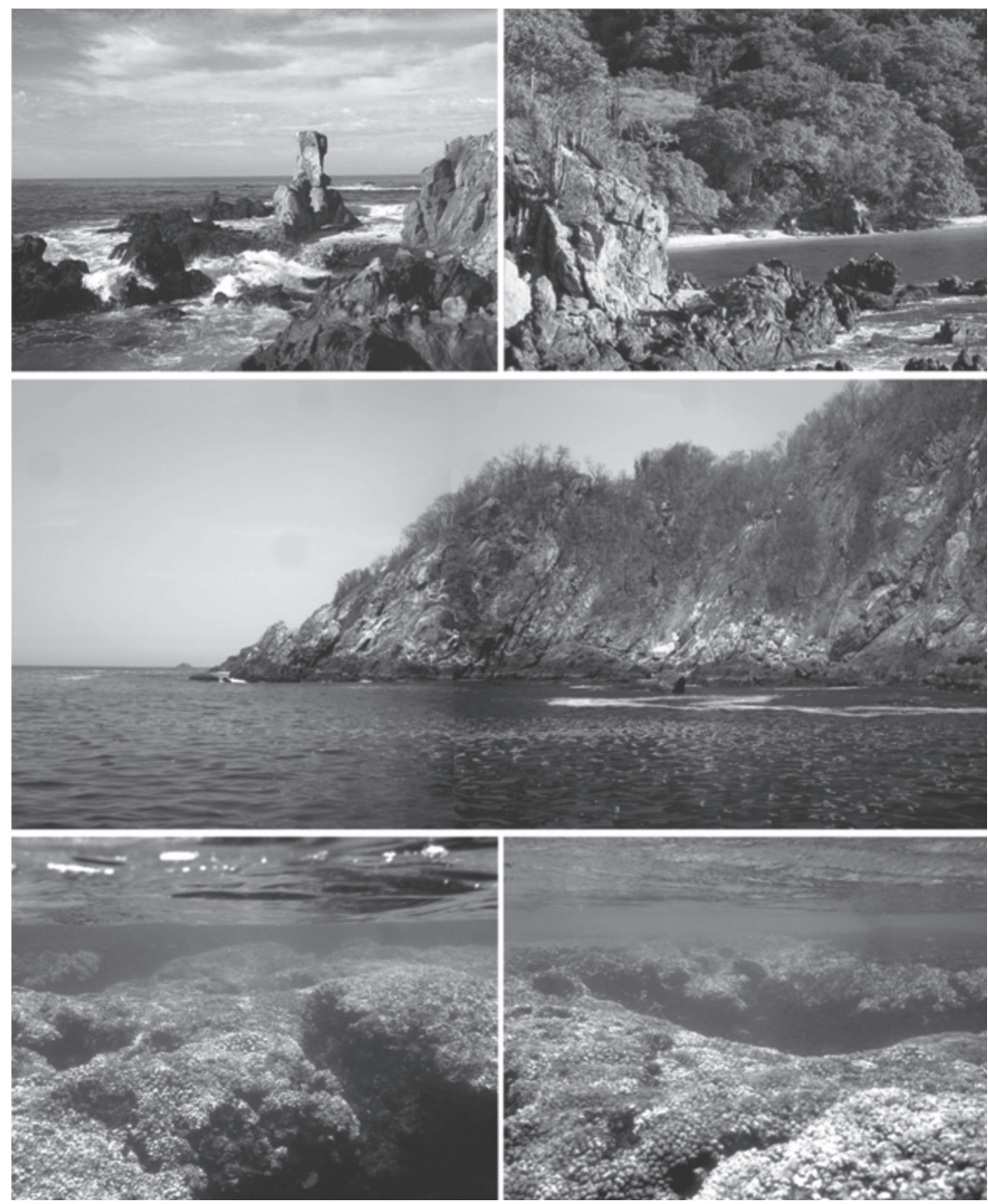

Fig. 5. Coastal landscape at Caleta de Chon and Manzanillo Beach. (Top-left) Sea stack on Manzanillo Beach; (Top-right) jointed and abraded sea cliff with sandy beach at Manzanillo; (Centre) sandstone beds at Caleta the Chon; and (Bottom) coral reef at Manzanillo Beach (Top photographs by C. Vazquez L.). 
vulnerability of use. Overall, Manzanillo Beach shows the highest scores (14.21) and the lowest ranking (7) making it the site with the greatest landscape value and with the best conservation potential if it is properly managed.

\section{DISCUSSION}

Coral reefs at Caleta de Chon and Manzanillo Beach remain as some of the typical coral reefs throughout the Eastern Pacific coast, conformed by species belonging to the genus Pocillopora (Glynn \& Ault 2000, Reyes-Bonilla 2003). Both reefs have an important area (up to $5343 \mathrm{~m}^{2}$ ) and a high coverage of live corals (up to $68 \%$ ) compared with other coral reefs from this region with a coral coverage ranging from 6.6 to $89 \%$ (Leyte-Morales et al. 2006, Victoria-Salazar 2007). Despite this relatively acceptable live coral coverage, the measured indicators for environmental degradation are positive. At both sites, total suspended solids (32 to $39 \mathrm{mg} / \mathrm{L}$ ) and chlorophyll $\left(1.3 \mathrm{mg} / \mathrm{m}^{3}\right)$ concentration is high, and such conditions are comparable to other coral reefs that survive under adverse conditions (Bell 1992, Edinger et al. 1998, Holmes et al. 2000). Major threats that both coral reefs face include the impact from land transformation and from direct human activities on these sites. At Caleta de Chon and Manzanillo Beach, the most severe impact on coral reefs seems to be caused by the high levels of sedimentation rates (1.6 and $0.6 \mathrm{~kg} / \mathrm{m}^{2} \mathrm{~d}$, respectively) and low water transparency (3.4 to $4.9 \mathrm{~m})$. Such conditions differ from well-conserved reefs where sedimentation rates are lower than $0.1 \mathrm{~kg} / \mathrm{m}^{2} \mathrm{~d}$ (Cortés \& Risk 1985, Rogers 1990, Edinger et al. 1998) and water transparency is superior to $20 \mathrm{~m}$ (Edinger et al. 1998, Holmes et al. 2000). High sedimentation rates and low water transparency are two recurrent stressors in coral reefs next to coastal transformation (Cortés \& Risk 1985, Edinger et al. 1998, Granja-Fernández \& López-Pérez 2009, Risk et al. 2009, Jordan et al. 2010). In our study area, the change of the status from Ecological Reserve of Cerro del Vigía to a residential tourist area, allowed deforestation and soil removal near coral reefs (Fig. 2). This land use change is causing erosion and sediment runoff that is reaching the marine ecosystem, creating conditions of high sedimentation and low water transparency. The problem increases when the morphology of the coast favors sediment catchment, as it is happening at the Caleta de Chon cove. This explains why sedimentation rate is higher at this site and indicates that this coral reef is under serious threat if such conditions persist. The excess of sedimentation can cause burial of benthic organisms and diminish light penetration (Rogers 1990, Fabricius et al. 2005, Yáñez et al. 2008). Worldwide, high sedimentation has been related to partial mortality in corals and to the hindering of larval recruitment due to the hard substrata burial (Hodgson \& Walton-Smith 1993, Morton 1994, Nugues \& Roberts 2003, Fonseca \& Cortés 2005). High sedimentation can also trigger the shift of species composition to most sediment-tolerant species as those belonging the genus Porites (Cortés 1990), in expense to the lost of coral coverage and diversity (Edinger et al. 1998, 2000, Shimoda et al. 1998, Cornell \& Carlson 2000). Low water transparency may cause a serious deficit in photosynthetic capability of corals affecting their growth (Stafford-Smith 1993, GranjaFernández \& López-Pérez 2009).

Biological indicators of conservation status indicate that the coral reef of Manzanillo Beach is the less conserved $(\mathrm{MI}=0.5)$. This coral reef shows clear signs of mechanical damage highly visible in its north zone, where the reef structure becomes shallower (1m depth), and snorkeling is more suitable for inexperienced tourists who visit the site. Contrary to Manzanillo Beach, mechanical damage in corals of Caleta de Chon is less frequent since the reef structure is below $3 \mathrm{~m}$ depth, and this site is visited only by experienced divers. Unrestricted recreational snorkeling and diving are important sources of coral reef deterioration in many tourist destinations around the world, as it happens in coral reefs in the Caribbean and the Red Sea, where both activities have caused a significant loss of coral coverage and diversity (Hawkins 
et al. 1999, Tratalos \& Austin 2001, Zakai \& Chadwick-Furman 2002). Scuba diving and snorkeling impact on Zihuatanejo coral reefs has occurred through the last decades, contrary to soil erosion near coral reefs that is a relative recent effect due to land use changes.

Anthropogenic causes of coral reef degradation are extending along tropical seas, and they are one of the main coral reef threats in coastal areas with poorly planned development. In the Caribbean, for example, indicators of coral reef degradation have coincided with our results: low coverage of living corals, high algae coverage, and high abundance of species indicative of high sedimentation rates are typical in Marine Protected Areas with low governability and community involvement (Camargo et al. 2009). Integrated terrestrial and underwater landscape assessment of both Caleta de Chon and Manzanillo Beach shows their high landscape value and conservation potential, outlining the need for a holistic approach in conservation and management strategies (Ramírez-Herrera et al. 2010). Some difficulties to meet NPAs objectives in "topdown" strategies include the integration of conservation policies at the different government levels that have their own strategies and different jurisdictions (Fig. 1). Moreover, the consolidation of collaborative links with local inhabitants, who usually depend upon natural resources, becomes a recurrent challenge to attain conservation objectives under "top-down" policies around the world (White et al. 1994, Cinner \& Pollnac 2004, BezauryCreel 2005, McClanahan et al. 2006, Tran 2006, Rodríguez-Martínez 2008, Camargo et al. 2009). In México, Federal and Municipal jurisdictions comprise a frequent barrier to accomplish conservation objectives (Fig. 1). While marine areas are under the jurisdiction of Federal authorities (e.g. SEMARNAT), coastal Ecological Reserves in Zihuatanejo are under Municipal jurisdiction by the Zihuatanejo Bay Fideicomiso (FIBAZI 2005) that exerts the faculty to create and modify the status of Ecological Reserves in order to meet local urban needs. Although both Federal and Municipal administrations can be not coordinated, they are similar in the fact that often they operate ignoring adjacent ecosystems (e.g. terrestrial and marine) and involvement of local communities. Our results on coral reef state of conservation show that this approach is proven inadequate to accomplish complete conservation objectives. Moreover, the use of natural spaces needs to be analyzed considering all their economic, sociological, geological, landscape and ecological aspects. Participation of local communities has been significant in the success of NPA's conservation objectives (Mascia 2003, McClanahan et al. 2006, Tran 2006, Rodríguez-Martínez 2008). It has been generally recognized that conventional, "top-down" coastal protection and management approaches do not meet the needs of communities in developing countries (Cohelo \& Manfrino 2007, Harborne et al. 2008, Camargo et al. 2009, Stamieszkin et al. 2009). It is also recognized that in countries where a substantial share of the Earth's marine biodiversity is found, top-down coastal protection and management efforts are too costly, both financially and in terms of scarce human resources, to be of much practical value for broad-scale national application (Govan et al. 2008). Recent studies advocate for the move from "top-down" (state or agency control) to more "bottom-up" (controlled by local communities) or locally-managed approaches for coastal protection and management, particularly in situations where little data are available (White et al. 1994, 2000, Johannes 1998a, b, Pomeroy \& Rivera-Guieb 2006, Ramírez-Herrera et al. 2010). This case has been confirmed in the Philippines and New Guinea, where marine resources (valuable commercial species) were more abundant in locally managed areas, without the intervention of government and market initiatives (McClanahan et al. 2006). This joint or 'comanagement' leads to better-informed decision taking, as traditional knowledge and local sources of information are integrated in such processes (White et al. 2000, Cinner et al. 2005, McClanahan et al. 2006, Walker et al. 2006). This approach also promotes enforcement and 
adaptive management of marine resources by and for the local users (Govan et al. 2008).

In the Pacific Ocean, the sustainable use of marine protected areas and reserves is being strengthened by application, modification, and merging of contemporary marine protection efforts with traditional conservation practices through a process of Community-Based Adaptive Management (CBAM). CBAM, in the simplest terms, is a management cycle whereby local stakeholders make a plan, implement the plan, check how it is going, revise the plan (if necessary), and carry on. The outcome is now commonly described as "locally-managed marine areas (LMMA)". LMMAs are areas of near shore waters that, together with their coastal resources, are largely or wholly managed at a local level by the coastal communities, landowning groups, partner organizations, and/or collaborative government representatives who reside or are based in the immediate area (White et al. 2000, Cinner et al. 2005, McClanahan et al. 2006, Walker et al. 2006). LMMAs differ from what is commonly known as a Marine Protected Area (MPA) in that LMMAs are characterized by local ownership and/or control, whereas MPAs are typified by top-down management approaches (LMMA Network 2008). Our results on coral reef state of conservation and landscape value in Zihuatanejo demonstrate that current "top-down" conservation policies do not support sustainable methods for ecosystem conservation in coastal areas subjected to increased urban development. Coral reefs conservation would require mitigation initiatives be taken in Zihuatanejo. First, land urbanization that encourages deforestation must be forbidden. This way soil erosion could be considerable reduced on this coastal area. Second, recreational scuba and snorkeling activities must be controlled and regulated by local stakeholders. Third, the carrying capacity of coral reefs must be considered in any coastal projects and resource use plans, and strategies for resource use must be developed involving the local community (Hawkins \& Roberts 1997, Zakai \& Chadwick-Furman 2002, Barker \& Roberts 2004). Finally, such information must be provided to the local community and choices of resource use must be taken by the local community, considering that resultant initiatives must be a complement of the complex livelihood strategies of local stakeholders (Cinner \& Pollnac 2004). Successful LMMA experiences strongly suggest that this approach must be promoted more extensively to manage effectively marine resources leading towards healthy ecosystems, abundant fish and other marine resource stocks, sustainable fisheries, and vibrant human communities.

\section{ACKNOWLEDGMENTS}

This research was partially funded by DGAPA IN123609, UNAM funds and CONACYT-107902 granted to M.T. Ramírez-Herrera. Thanks to Violeta Rangel and Ana Vergara for field assistance. Hilda Rivas Solórzano, Rosaura Páez Bistrain and Julien Neméry kindly provided logistic support. José Antonio Navarrete assisted with GIS database management and mapping. Special acknowledge to the local community at Zihuatanejo and Barra de Potosi, in particular Laura Kelly and Juani Martínez Bello.

\section{RESUMEN}

Las estrategias integrales son clave para lograr efectividad en la conservación de las áreas costeras. Para discutir la importancia de las estrategias holísticas en iniciativas de conservación, usamos como caso de estudio los arrecifes coralinos de Zihuatanejo Guerrero. En primer lugar, analizamos el valor paisajístico terrestre y marino de la zona costera y posteriormente usamos indicadores biológicos y ambientales de degradación en arrecifes coralinos. El valor paisajístico mostró que Manzanillo Beach tiene el mayor potencial para desarrollar iniciativas de conservación ( $\mathrm{TtV}=14.2)$. No obstante, ambos arrecifes se enfrentan a elevados niveles de sedimentación (hasta $1.16 \mathrm{~kg} / \mathrm{m}^{2} \mathrm{~d}$ ) y baja transparencia del agua $(<5 \mathrm{~m})$ causados por el aumento de la erosión de la costa, como consecuencia del cambio de uso del suelo. La alta cobertura de corales muertos (23.6\%) y algas (hasta un 29\%) en los arrecifes reflejan su manejo inadecuado. Estas condiciones son resultado de las estrategias de conservación usadas principalmente por las autoridades gubernamentales, que en muchos casos no se encuentran coordinadas y no consideran a la población local en el manejo de los recursos. Estos resultados 
confirman la importancia de las estrategias de conservación con una visión holística del ecosistema terrestre-marino en las áreas costeras. Estas iniciativas deben incluir a la población local en el manejo y la toma de decisiones.

Palabras clave: conservación, arrecifes coralinos, costa del Pacífico mexicano, manejo costero, políticas gubernamentales, áreas naturales protegidas.

\section{REFERENCES}

Ban, N.C. 2009. Minimum data requirements for designing a set of marine protected areas, using commonly available abiotic and biotic datasets. Biodivers. Conservat. 18: 1829-1845.

Barker, N.H.L. \& C.M. Roberts. 2004. Scuba Diver Behavior and the management of diving impacts on coral reefs. Biol. Conservat. 120: 481-489.

Bartholomew, A., J.A. Bohnsack, S.G. Smith, J.S. Ault, D.E. Harper \& D.B. McClellan. 2008. Influence of marine reserve size and boundary length on the initial response of exploited reef fishes in the Florida Keys Natural Marine Sanctuary, USA. Landsc. Ecol. 23: 55-65.

Bell, P.R.F. 1992. Eutrophication and coral reefs. Some examples in the Great Barrier Reef lagoon. Water. Res. 26: 553-568.

Bezaury-Creel, J.E. 2005. Protected areas and coastal and ocean management in México. Ocean Coast. Manag. 48: 1016-1046.

Camargo, C., J.H. Maldonado, E. Alvarado, R. MorenoSánchez, S. Mendoza, N. Manrique, A. Mogollón, J.D. Osorio, A. Grajales \& J.A. Sánchez. 2009. Community involvement in management for maintaining coral reef resilience and biodiversity in southern Caribbean marine protected areas. Biodivers. Conservat. 18: 935-956.

Carriquiry, J.D. \& H. Reyes-Bonilla. 1997. Estructura de la comunidad y distribución geográfica de los arrecifes coralinos de Nayarit, Pacífico de México. Cienc. Mar. 23: 227-248.

Cinner, J.E. \& R.B. Pollnac. 2004. Poverty, perceptions and planning: why socioeconomics matter in the management of Mexican reefs. Ocean Coast. Manag. 47: 479-493.

Cinner, J.E., M.J. Marnane, T.R. McClanahan, T.H. Clark \& J. Ben. 2005. Trade, tenure and tradition: influence of sociocultural factors on resource use in Melanesia. Conservat. Biol. 19: 1469-1477
Coblentz, B.E. 1997. Subsistence concumption of coral reef fish suggest non-sustainable extraction. Conservat. Biol. 11: 559-561.

Cohelo, V.R. \& C. Manfrino. 2007. Coral community decline at a remote Caribbean island: Marine no-take reserves are not enough. Aquat. Conservat. Mar. Freshwat. Ecosyst. 17: 666-685.

CONABIO. 2009. Áreas Marinas Prioritarias. Tlacoyunque. (Downloaded: July 24, 2010, www.conabio.gob. $\mathrm{mx} /$ conocimiento/regionalizacion/doctos/rmp_031. html).

CONANP. 2006. Programa de conservación y manejo Parque Nacional Cabo Pulmo. Comisión Nacional de Áreas Naturales Protegidas, Distrito Federal, México.

CONANP. 2009. Comisión Nacional de Areas Naturales Protegidas. ¿Qué son las AP?. (Downloaded: May 29, 2009, www.conanp.gob.mx/q_anp.html).

Cornell, H.V. \& R.H. Carlson. 2000. Coral species richness: ecological versus biogeographical influences. Coral Reefs 19: 37-49.

Cortés, J. 1990. Coral reef decline in Golfo Dulce, Costa Rica, Eastern Pacific: anthropogenic and natural disturbances. Ph.D. Thesis, University of Miami, Miami, USA.

Cortés, J. \& M.J. Risk. 1985. A reef under siltation stress: Cahuita, Costa Rica. Bull. Mar. Sci. 36: 339-356.

Crosby, M.P., G. Brighouse \& M. Pichon. 2002. Priorities and strategies for addressing natural and anthropogenic threats to coral reefs in Pacific Island Nations. Ocean Coast. Manag. 45: 121-137.

Edinger, E.N., J. Jompa, G.V. Limmon, W. Widjatmoko \& M.J. Risk. 1998. Reef degradation and coral biodiversity in Indonesia: effects of land-based pollution, destructive fishing practices and changes over time. Mar. Pollut. Bull. 36: 617-630.

Edinger, E.N., G.V. Limmon, J. Jompa, W. Widjatmoko, J.M. Heikoop \& M.J. Risk. 2000. Normal coral growth rates on dying reefs: are coral growth rates good indicators of reef health?. Mar. Pollut. Bull. 40: 404-425.

Fabricius, K., G. De'ath, L. McCook, E. Turak \& D.M. Williams. 2005. Changes in algal, coral and fish assemblages along water quality gradients on the inshore Great Barrier Reef. Mar. Pollut. Bull. 51: 384-398. 
FIBAZI. 2005. Plan director de desarrollo urbano de Ixtapa-Zihuatanejo. Fideicomiso Bahía de Zihuatanejo, Guerrero, México.

Fonseca, A.C. \& J. Cortés. 2005. Non-colonial coral macro-borers as indicators of coral reef status in the south Pacific of Costa Rica. Rev. Biol. Trop. 54: 101-115.

Glynn, P.W. \& J.S. Ault. 2000. A biogeographic analysis and review of the far eastern Pacific coral reef region. Coral Reefs 19: 1-23.

Gómez, E.D., P.M. Aliño, H.T. Yap \& W.Y. Licuanan. 1994. A Review of the status of Philippine reefs. Mar. Pollut. Bull. 29: 62-68.

Govan, H., W. Aalbersberg, A. Tawake \& J.E. Parks. 2008. Locally-Managed Marine Areas: A guide for practitioners. The Locally-Managed Marine Area Network (Downloaded: October 14, 2009, lmmanetwork.org/ Site_Documents/Grouped/LMMAGuide.pdf).

Granja-Fernández, M.R. \& R.A. López-Pérez. 2009. Sedimentación en comunidades arrecifales de Bahías de Huatulco, Oaxaca, México. Rev. Biol. Trop. 56: $1179-1187$

Harborne, A.R., P.J. Mumby, C.V. Kappel, C.P. Dahlgreen, F. Micheli, K.E. Holmes, J.N. Sanchirico, K. Broad, I.A. Elliott \& D.R. Brumbaugh. 2008. Reserve effects and natural variation in coral reef communities. J. Appl. Ecol. 45: 1010-1018.

Hawkins, J.P. \& C.M. Roberts. 1997. Estimating the carrying capacity of coral reefs for scuba diving. Proc. $8^{\text {th }}$ Int. Coral Reef Symp. 1: 1923-1926.

Hawkins, J.P. \& C.M. Roberts. 2004. Effects of artisanal fishing on Caribbean coral reefs. Conservat. Biol. 18: $215-226$.

Hawkins, J.P., C.M. Roberts, T. Vant'Hof, K. De Meyer, J. Tratalos \& C. Aldam. 1999. Effects of recreational scuba diving on Caribbean coral and fish communities. Conservat. Biol. 13: 888-897.

Herbert, M.E., P.B. Mcintyre, P.J. Doran, J.D. Allan \& R. Abell. 2010. Terrestrial reserve networks do not adequately represent aquatic ecosystems. Conservat. Biol. 24: 1002-1011.

Hodgson, G. 1999. A global assessment of human effects on coral reefs. Mar. Pollut. Bull. 38: 345-355.

Hodgson, G. \& F.G. Walton-Smith. 1993. Sedimentation damage to reef corals, global aspects of coral reefs: Health, hazards and history. University of Miami, Miami, EEUU.
Holmes, K.E., E.N. Edinger, Hariyadi, G.V. Limmon \& M.J. Risk. 2000. Bioerosion of live massive corals and branching coral rubble on Indonesian Coral Reefs. Mar. Pollut. Bull. 4: 606-617.

INE. 1998. Programa de manejo Parque Nacional Marino Arrecifes de Cozumel, Quintana Roo, México. Instituto Nacional de Ecología, Distrito Federal, México.

INEGI, 2008. Instituto Nacional de Estadística y Geografía. Anuario estadístico de Guerrero 2008. (Downloaded: October 14, 2009,www.inegi.org.mx/prod_serv/contenidos/espanol/catalogo/Default.asp).

Jameson, S.C., M.S.A. Ammar, E. Saadalla, H.M. Mostafa \& B. Riegl. 1999. A coral damage index and its application to diving sites in the Egyptian Red Sea. Coral Reefs 18: 333-339.

Johannes, R.E. 1998a. Government-supported, villagebased management of marine resources in Vanuatu. Ocean Coast. Manag. 40: 165-186.

Johannes, R.E. 1998b. The case for data-less marine resource management: Examples from tropical nearshore fisheries. Trends. Ecol. Evol. 13: 243-246.

Jordan, L.K.B., K.W. Banks, L.E. Fisher, B.K. Walker \& D.S. Gilliam. 2010. Elevated sedimentation on coral reefs adjacent to a beach nourishment project. Mar. Pollut. Bull. 60: 261-271.

Leyte-Morales, G.E., L.M. Hernández-Ballesteros, R.A. López-Pérez, H. Reyes-Bonilla \& L.E. CalderónAguilera. 2006. Arrecifes coralinos en las costas de Guerrero: Ixtapa-Zihuatanejo. III Congreso Mexicano de Arrecifes de coral. (Downloaded: October 14, 2009, http://public.jubiloweb.com/somac/congreso/ III.\%20Trabajos\%20Panor\%C3\%A1 micos/Posters/ Leyte.htm).

LMMA Network. 2008. The Locally-Managed Marine Area Network 2007 Annual Report. The Locally-Managed Marine Area Network. (Downloaded: October 14, 2009, www.lmmanetwork.org/Site_Documents/ Grouped/LMMA2007ARFINAL.pdf).

López-Pérez, R.A. \& A. López-García. 2009. Identification of priority conservation sites for reef building corals in Oaxaca state, Mexico. Hidrobiológica 18: 209-213.

Mascia, M.B. 2003. The human dimension of coral reef marine protected areas: recent social science research and its policy implications. Conservat. Biol. 17: 630-632.

McClanahan, T.R. 2002. The near future of coral reefs. Environ. Conservat. 29: 460-483. 
McClanahan, T.R., M.J. Marnane, J.E. Cinner \& W.E. Kiene. 2006. A comparison of marine protected areas and alternative approaches to coral reef management. Curr. Biol. 16: 1408-1413.

Moberg, F. \& C. Folke. 1999. Ecological goods and services of coral reef ecosystems. Ecol. Econ. 29: 215-233.

Moreno-Casasola, P., E. Peresbarbosa-Rojas \& A.C. Travieso Bello. 2005. Manejo costero integral: el enfoque municipal. Instituto de Ecología, Xalapa, México.

Morton, B. 1994. Hong Kong's coral communities: Status, threats and management plans. Mar. Pollut. Bull. 29: $74-83$.

Nuges, M.M. \& C.M. Roberts. 2003. Coral mortality and interaction with algae in relation to sedimentation. Coral Reefs 22: 507-516.

Panizza, M. 2001. Geomorphosites: Concepts, methods and examples of geomorphological survey. Chin. Sci. Bull. 46: 4-6.

Pereira, P., D. Pereira \& M.I. Caetano-Alves. 2007. Geomorphosite assessment in Montesinho Natural Park (Portugal). Geograph. Helv. 62: 159-168.

Pomeroy, R.S. \& R. Rivera-Guieb. 2006. Fishery comanagement: a practical handbook. CAB International, Oxfordshire. Available at the International Development Research Centre (IDRC) (Downloaded: October 14, 2009, www.idrc.ca/openebooks/184-1/).

Ramírez-Herrera, M.T., R. Novella \& N. Bassols-Barrera. 2010. Conservación del paisaje y geositios de la costa Norte de Michoacán, México. Rev. geogr. Norte Gd. 46: $105-121$.

Reyes-Bonilla, H. 2003. Biogeografía y ecología de los corales hermatípicos del Pacífico, p. 207-222. In S. Salazar-Vallejo \& N.E. González (eds.). Biodiversidad marina y costera de México. CONABIO/CIQRO, Chetumal, Quintana Roo, México.

Reynard, E. 2005. Geomorphosites et paysages. Géomorphologie: relief, processus, environment 3: 181-188.

Rioja-Nieto, R. \& C. Sheppard. 2008. Effects of management strategies on the landscape ecology of a Marine Protected Area. Ocean Coast. Manag. 51: 397-404.

Risk, M.J., B.E. Lapointe, O.A. Sherwood \& B.J. Bedford. 2009. The use of $\delta^{15} \mathrm{~N}$ in assessing sewage stress on coral reefs. Mar Pollut. Bull. 58: 793-802.
Rodríguez-Martínez, R.E. 2008. Community involvement in marine protected areas: The case of Puerto Morelos reef, México. Ocean Coast. Manag. 88: 1151-1160.

Rogers, C.S. 1990. Responses of coral reefs and reef organisms to sedimentation. Mar. Ecol. Progr. 62: 185-202.

Rogers, C.S., G. Garrison, R. Grober, Z. Hillis \& M. Franke. 1994. Coral reef monitoring manual for the Caribbean and Western Atlantic. Virgin Islands National Park, Virgin Islands, USA.

Rovere, A., V. Parravicini, M. Firpo, C. Morri, G. Albertelli \& C.N. Bianchi. 2007. Emergenze nat uralisti che del l'Area Mari na Protetta di Bergeggi (Sv): Integrazione di aspetti biologici, ecologici e geomorfologici. Biol. Mar. Mediterr. 142: 86-87.

Selkoe, K.A., B.S. Halpern, C.M. Ebert, E.C. Franklin, E.R. Selig, K.S. Casey, J. Bruno \& R.J. Toonen. 2009. A map of human impacts to a "pristine" coral reef ecosystem, the Papahãnaumokuãkea Marine National Monument. Coral Reefs 28: 365-650.

SEMARNAT. 2002. Acuerdo por el que se determinan como áreas naturales protegidas, con la categoría de santuarios, a las zonas de reserva y sitios de refugio para la protección, conservación, repoblación, desarrollo y control de las diversas especies de tortuga marina, ubicadas en los estados de Chiapas, Guerrero, Jalisco, Michoacán, Oaxaca, Sinaloa, Tamaulipas y Yucatán, identificadas en el decreto publicado el 29 de octubre de 1986. Secretaria del Medio Ambiente y Recursos Naturales, Distrito Federal, México.

SEMARNAT. 2010. Relación de autorizaciones para el cambio de uso del suelo en terrenos forestales. (Downloaded: October 14, 2009, www.semarnat.gob. mx/estados/guerrero/temas/recursosforestales/Documents/Cambio\%20de\%20Uso\%20del\%20Suelo\%20 en\%20Terrenos\%20Forestales\%2008-2010.pdf).

Shimoda, T., T. Ichikawa \& Y. Matsukawa. 1998. Nutrient conditions and their effects on coral growth in reefs around Ryukyu Islands. Bull. Natl. Res. Inst. Fish. Sci. 12: $71-80$

Sokal, R.R. \& F.J. Rolf. 1981. Biometry. Freeman \& Co, New York, New York, USA.

Stafford-Smith, M.G. 1993. Sediment-Rejection efficiency of 22 species of Australian Scleractinian corals. Mar. Biol. 115: 229-243.

Stamieszkin, K., J. Wielgus \& R.L. Gerber. 2009. Management of a marine protected area for sustainability and conflict resolution: Lesson from Loreto Bay National Park (Baja California Sur, México). Ocean. Coast. Manag. 52: 449-458. 
Tran, K.C. 2006. Public perception of development issues: Public awareness can contribute to sustainable development of a small island. Ocean Coast. Manag. 49: 367-383.

Tratalos, J.A. \& T.J. Austin. 2001. Impacts of recreational scuba diving on coral communities of the Caribbean island of Grand Cayman. Biol. Conservat. 102: 67-75.

Vázquez-Domínguez, E., C. Aguilar, V. Aguilar \& V. Arenas. 1998. Áreas prioritarias marinas de alta biodiversidad, p. 109-126. In E. Arriaga-Cabrera, L. Vázquez-Domínguez, J. González-Cano, R. JiménezRosemberg, E. Muñoz-López \& V. Aguilar-Sierra (eds.). Regiones Prioritarias Marinas de México. Comisión Nacional para el Conocimiento y Uso de la Biodiversidad, México DF, México.

Victoria-Salazar, I. 2007. Caracterización de la comunidad de corales escleractinios de Playa las Gatas, Zihuatanejo, Guerrero, México: Fisiografía y estructura comunitaria. Thesis, Universidad Nacional Autónoma de México, México DF, México.

Walker, R.C.J., D.J. Ponce-Taylor, A. McVean, H. Waska, J.F. Taylor, J. Comley \& P.S. Raines. 2006. An environmental management plan for snorkel based tourism as a form of alternative livehold-Sian ka'an UNESCO Biosphere reserve, Mexico. Proc. $10^{\text {th }}$ Int. Coral Reef. Symp. 1: 1903-1910.

White, A., L.Z. Hale, Y. Renard \& L. Cortesi. 1994. Collaborative and community management of coral reefs: Lessons from experience. Kumarian, Bloomfield, Connecticut, USA.

White, A.T., H.P. Vogt \& T. Arin. 2000. Philippine coral reefs under threat: the economic losses caused by reef destruction. Mar. Pollut. Bull. 40: 598-605.

World Database on Protected Areas (WDPA). 2004. World Database on Protected Areas. WDPA, Washington D.C., USA.

Yáñez, C.B., J.L Carballo, C. Olabarria \& J.J. Barrón. 2008. Recovery of macrobenthic assemblages following experimental sand burial. Oceanologia 50: 391-420.

Zakai, D. \& N.E. Chadwick-Furman. 2002. Impacts of intensive recreational diving on reef corals at Eilat, northern Red Sea. Biol. Conservat. 105: 179-187. 
